\title{
Contribution of different vegetable types to exogenous nitrate and nitrite exposure
}

\author{
Manuela Correia, Ângela Barroso, M. Fátima Barroso, Débora Soares, M.B.P.P. Oliveira, \\ Cristina Delerue-Matos
}

\begin{abstract}
This study reports the levels of nitrate and nitrite of 34 vegetable samples, including different varieties of cabbage, lettuce, spinaches, parsley and turnips, collected in several locations of an intensive agricultural area (Modivas, Vila do Conde, northern Portugal). Nitrate levels ranged between 54 and $2440 \mathrm{mg} \mathrm{NO}_{3}^{-} \mathrm{kg}^{-1}$. while nitrite levels ranged between 1.1 and $57 \mathrm{mg} \mathrm{NO}_{2}^{-} \mathrm{kg}^{-1}$. The maximum residue levels established for nitrate in spinach and lettuce samples were not exceeded. Nitrate and nitrite levels reported in the literature for the same type of samples are reviewed, as well as the contribution of vegetables to nitrate and nitrite dietary exposure of populations.
\end{abstract}

Keywords: Nitrate, Nitrite, Vegetables, Dietary exposure

\section{Introduction}

Nitrate and nitrite are natural constituents of plant material. Although nitrate is apparently non-toxic below maximum residue levels (MRLs), it may be endogenously transformed to nitrite which can react with amines and amides to produce $N$-nitroso compounds (Santamaria, 2006; Yordanov, Novakova, \& Lubenova, 2001). These have been related to an increased risk of gastric, oesophageal, nasopharyngeal and bladder cancers (Choi, Chung, Lee, Shin, \& Sung, 2007). For this reason the determination of nitrate and nitrite in food has received increased attention and several recent studies have addressed the dietary exposure of human population to these compounds (Menard, Heraud, Volatier, \& Leblanc, 2008; Thomson, Nokes, \& Cressey, 2007).

According to the literature, the primary dietary sources of nitrate and nitrite include vegetables, processed and cured meat, fish and poultry (to which nitrite has been added), and possibly water, especially if there is runoff or contamination by nitrate from agricultural sources. Plant foods are the primary sources of nitrate (80$95 \%$ ), while processed and cured meat are the primary sources of nitrite (Pennington, 1998; Ximenes, Rath, \& Reyes, 2000).

About $5 \%$ of the dietary nitrate is reduced to nitrite in saliva and the gastrointestinal tract. This value can reach $20 \%$ for individuals with a high rate of conversion (Thomson et al., 2007). Methemoglobinemia is another health hazard attributed to nitrite, a condition where reduced iron $\left(\mathrm{Fe}^{2+}\right)$ in haemoglobin is oxidised by nitrite to
$\mathrm{Fe}^{3+}$, thus reducing the total oxygen-carrying capacity of the blood (Santamaria, 2006).

Nitrate concentrations in vegetables depend on the biological properties of the plant culture, (day)light intensity, type of soil, temperature, humidity, frequency of plants in the field, plant maturity, vegetation period, harvesting time, size of the vegetable unit, storage time and source of nitrogen (Tamme et al., 2006). Nitrogen fertilisation and light intensity have been identified as the major factors that influence nitrate content in vegetables (Gruda, 2005; Santamaria, 2006). Even among different samples of the same vegetable varieties, the range of concentrations may be large (Prasad \& Chetty, 2008; Tamme et al., 2006; Thomson et al., 2007). Variations, within site, for plants growing in the same plot can be explained by differences in soil mineral nitrogen, and individual plant growth in response to localised areas of soil compaction, or variability in soil $\mathrm{pH}$ (Weightman, Dyer, Buxton, \& Farrington, 2006).

Generally, nitrate-accumulating vegetables belong to the families of Brassicaceae (rocket, radish, mustard), Chenopodiaceae (beetroot, Swiss chard, spinach) and Amarantaceae; but also Asteraceae (lettuce) and Apiaceae (celery, parsley) include species with high nitrate contents (Santamaria, 2006). The differing locations of the nitrate reductase activity, as well as the differing degrees of nitrate absorption and transfer in the plant may be responsible for the varying capacities of vegetable species to accumulate nitrate (Santamaria, 2006).

Although vegetables are one of the major sources of dietary exposure to nitrate, numerous studies have reported that the consumption of vegetables decreases in incidences of cancer. This is 
mainly due to antioxidant compounds (ascorbate, tocopherol, b-carotene, phenol compounds, indol) that suppress the formation of carcinogenic agents, such as nitrosamines (Chung et al., 2003). Therefore, it has been argued that naturally occurring nitrates in foods are not toxic, which is one of the reasons for the absence of regulations controlling nitrates in vegetables in some countries (Chung et al., 2003). The European Commission has established maximum levels (MLs) for nitrate in lettuces $\left(2500-3500 \mathrm{mg} \mathrm{kg}^{-1}\right.$ for summer harvest and $4000-4500 \mathrm{mg} \mathrm{kg}^{-1}$ for winter harvest) and spinaches (2500 $\mathrm{mg} \mathrm{kg}^{-1}$ for summer harvest, $3000 \mathrm{mg} \mathrm{kg}^{-1}$ for winter harvest and $2000 \mathrm{mg} \mathrm{kg}^{-1}$ for frozen spinach) (European Commission Regulation (EC) No 1881/2006). In China, a suggested maximum level of nitrate in vegetables of $3100 \mathrm{mg} \mathrm{kg}^{-1}$ has been established (Santamaria, 2006) and the tolerance limit for nitrite is $4 \mathrm{mg} \mathrm{kg}^{-1}$ (Zhou, Wang, \& Wang, 2000).

Recent researches suggest that dietary nitrate may have beneficial effects, based on the hypothesis that nitric oxide formed in the stomach from dietary nitrate has antimicrobial effects on gut pathogens and a role in host defence (Santamaria, 2006).

The Vila do Conde region, northern Portugal, is classified as a vulnerable area because of the high nitrate concentrations that may be found in water and soil samples, as a consequence of intensive agricultural activity (Gonçalves, Esteves da Silva, \& Alpendurada, 2006). The evaluation of the nitrate and nitrite levels in horticultural products grown in this area is therefore important in order to assess their safety for consumers. These products play an important role in the population's diet, being consumed on a daily basis, especially in the form of soup. In this study, the levels of nitrate and nitrite were determined in 34 vegetable samples, consisting of different varieties of cabbage, lettuce, spinach, parsley and turnip, collected in Vila do Conde, northern Portugal.

\section{Materials and methods}

\subsection{Chemicals}

All reagents used in this study were of analytical grade. De-ionised water ( $18 \mathrm{M} \mathrm{X} \mathrm{cm}^{-1}$ ) was used for preparing all the solutions and for sample extraction. Potassium nitrite (Riedel-de Häen), potassium nitrate (Riedel-de Häen), sulphanilamide chloride (Sig-

ma-Aldrich), N-(1-naphthyl)ethylenediamine dihydrochloride (Riedel-de Häen), potassium hexacyanoferrate (II) (Riedel-de Häen), ammonium chloride (Merck), hydrochloric acid (Riedel-de Häen), zinc acetate (Fluka), disodium tetraborate (Merck) and glacial acetic acid (Merck) were used.

\subsection{Vegetable samples}

In total, 34 vegetable samples (Portuguese cabbage (Brassica oleracea var. costata), kale (B. oleracea var. acephala), turnip and turnip sprouts ("grelos") (Brassica rapa var. rapa), lettuce (Lactuca sati$v a$ ), spinach (Spinacea oleracea), and parsley (Petroselinum crispum)), from several different producers, were collected in different locations of Modivas, Vila do Conde municipality, in February, 2007. The vegetable samples were labelled and frozen in plastic bags after collection. Just before analysis they were cut into small pieces and macerated in a blender.

\subsection{Extraction and analysis}

Nitrate and nitrite concentrations were determined using a standard methodology (ISO 6635:1984 (E)). Briefly, the method consists in extracting a test portion of the vegetable (10 g) with hot water, precipitating the proteins by addition of solutions of potassium hexacyanoferrate (II) and zinc acetate, and filtering the precipitate. The nitrate is then reduced to nitrite in a column containing metallic cadmium. The addition of sulphanilamide chloride and $\mathrm{N}$-(1-naphthyl)ethylenediamine to the nitrite-containing solutions allows the measurement of the red complex obtained, at $538 \mathrm{~nm}$. The limit of detection (LOD) was $0.093 \mathrm{mg} \mathrm{NO}_{2}^{-} \mathrm{kg}^{-1}$ while the limit of quantification (LOQ) was $0.31 \mathrm{mg} \mathrm{NO}-\mathrm{kg}^{-1}$.

\section{Results and discussion}

As was pointed out by Menard et al. (2008), although the value of national monitoring programmes is unquestionable, these programmes do not account for the variability of food composition across regions. Therefore it is important to perform studies addressing areas and regions where the levels of nitrate and/or nitrite may be potentially higher. Regarding the production of fresh vegetables in northern Portugal, Vila do Conde is an important region. Cultures are grown both in the open air and greenhouses and large quantities of fertilisers are used. A study conducted in 2005 revealed that $74 \%$ of groundwater samples obtained from domestic wells, with an approximate depth of $15 \mathrm{~m}$, presented nitrate concentrations higher than the Portuguese guideline value for drinking water (50 $\mathrm{mg} \mathrm{l}^{-1}$ ) (Silva et al., 2006). Furthermore, vegetables play an important role in the population's diet. The vegetables selected for this study are some of the most commonly consumed and also the ones that were available during the collection period. Individual results obtained for nitrate and nitrite levels on the studied samples are presented in Table 1, while average contents are shown in Table 2.

The results obtained show a considerable variation in the nitrate contents within the same vegetable species. As previously described, the nitrate content in vegetables depends on many factors, such as soil properties, fertiliser usage, cultivation and weather conditions, which are unknown and whose effects are impossible to account for in this study. Considering all these different factors, wide ranges and large standard deviations may occur (Pennington, 1998).

Regarding the nitrate content, $82 \%$ of the samples presented nitrate levels lower than $1000 \mathrm{mg} \mathrm{kg}^{-1}$. The average nitrate contents for Portuguese cabbage and kale (547 and $472 \mathrm{mg} \mathrm{kg}^{-1}$, respectively) were similar and comparable to the results obtained for cabbages in other countries (Table 3), particularly those reported in Estonia (437 $\mathrm{mg} \mathrm{kg}^{-1}$ ) and France (498 $\mathrm{mg} \mathrm{kg}^{-1}$ ) (Menard et al., 2008; Tamme et al., 2006).

For turnip sprouts ("Grelos"), the nitrate mean value was $489 \mathrm{mg} \mathrm{kg}^{-1}$ while, for the two turnip samples, the average value was $444 \mathrm{mg} \mathrm{kg}^{-1}$. Comparing with the nitrate contents presented in Table 3, these are in the range of those found for turnip in Estonia and France (307 and $657 \mathrm{mg} \mathrm{kg}^{-1}$, respectively) and are lower than those reported in Brazil and China (2098 and $2127 \mathrm{mg} \mathrm{kg}^{-1}$, respectively) (Ximenes et al., 2000; Zhou et al., 2000).

In our study, the highest nitrate value was obtained for a parsley sample $\left(2440 \mathrm{mg} \mathrm{kg}^{-1}\right)$. According to the literature, typical nitrate contents in parsley may be considered high, and are usually in the range 1000-2500 $\mathrm{mg} \mathrm{kg}^{-1}$ (Santamaria, 2006).

The maximum residue levels established for nitrate in spinach and lettuce samples were not exceeded but the mean values, 1112 and $1156 \mathrm{mg} \mathrm{kg}^{-1}$, respectively, were the highest of all the analysed samples (Table 2).

With the exception of lettuce, the vegetables considered in this study are usually consumed after cooking, either after boiling or included in soups. Cooking vegetables has been shown to reduce nitrate concentrations by up to $75 \%$ (Menard et al., 2008). In the first case, the boiling water is usually discarded and therefore a reduction in nitrate levels is expected. In regard to the soups, although 
Table 1

Nitrate and nitrite contents $\left(\mathrm{mg} \mathrm{kg}^{-1}\right)$ in the analysed vegetable samples.

\begin{tabular}{|c|c|c|}
\hline Vegetable sample & $\begin{array}{l}\text { Nitrate } \\
\left(\mathrm{mg} \mathrm{kg}^{-1}\right)\end{array}$ & $\begin{array}{l}\text { Nitrite } \\
\left(\mathrm{mg} \mathrm{kg}^{-1}\right)\end{array}$ \\
\hline Portuguese cabbage 1 & 41 & 1.4 \\
\hline Portuguese cabbage 2 & 162 & 30.0 \\
\hline Portuguese cabbage 3 & 336 & 1.9 \\
\hline $\begin{array}{l}\text { Portuguese cabbage } 4 \\
\text { Portuguese cabbage } 5\end{array}$ & $\begin{array}{l}405 \\
643\end{array}$ & $\begin{array}{r}20.5 \\
1.9\end{array}$ \\
\hline Portuguese cabbage 6 & 733 & 0.9 \\
\hline Portuguese cabbage 7 & 804 & 17.3 \\
\hline Portuguese cabbage 8 & 863 & 9.1 \\
\hline Portuguese cabbage 9 & 939 & 3.7 \\
\hline Turnip sprouts 10 & 54 & 1.3 \\
\hline Turnip sprouts 2 & 178 & 1.1 \\
\hline Turnip sprouts 9 & 305 & 1.3 \\
\hline Turnip sprouts 5 & 349 & 39.8 \\
\hline Turnip sprouts 6 & 364 & 1.8 \\
\hline Turnip sprouts 1 & 728 & 1.1 \\
\hline Turnip sprouts 4 & 1447 & 57.0 \\
\hline Kale 8-1 & 41 & 4.4 \\
\hline Kale 10 & 90 & 2.9 \\
\hline Kale 8-2 & 180 & 2.3 \\
\hline Kale 6 & 288 & 3.1 \\
\hline Kale 9 & 572 & 4.1 \\
\hline Kale 7 & 811 & 1.4 \\
\hline Kale 11 & 1319 & 1.2 \\
\hline Colza 8 & 73 & 2.2 \\
\hline Spinach 8 & 797 & 13.8 \\
\hline Spinach 11 & 1427 & 5.2 \\
\hline Lettuce 6 & 1156 & 2.6 \\
\hline Parsley 12 & 9 & 1.3 \\
\hline Parsley 3-1 & 136 & 3.0 \\
\hline Parsley 4 & 866 & 2.1 \\
\hline Parsley 3-2 & 1006 & 11.0 \\
\hline Parsley 7 & 2441 & 13.4 \\
\hline Turnip 10 & 234 & 1.1 \\
\hline Turnip 9 & 654 & 1.4 \\
\hline
\end{tabular}

Numbers refer to the collection site.

there is a reduction in nitrate content in the vegetable tissue, nitrates are transferred to the liquid phase. In fact the determination of nitrates in vegetable samples, in many analytical methods, is based on nitrate extraction from test portions with hot water. In the final soup, nitrate concentration may be increased if the water used in the preparation has a high nitrate content. In the region considered in this study this possibility exists, since the water supply is not available in all the households. Another "common" idea is that boiling increases water safety, which may be true in the case of microbiological contamination but, in the case of nitrate, will have an opposite effect as an increase in nitrate concentration may occur due to water evaporation.

According to the literature, vegetables were shown to contain nitrates at varying levels, ranging from 1 to $10,000 \mathrm{mg} \mathrm{kg}^{-1}$. A value of $10,800 \mathrm{mg} \mathrm{kg}^{-1}$ has been reported for a celery sample grown using the hydroponic cultivation method (Zhong, Hu, \& Wang, 2002).

The time of the day the plants were harvested was shown to have a significant effect on the variability of nitrate levels in lettuce, although with no consistent temporal trends (Weightman et al., 2006). However other studies failed to detect a significant relationship between nitrate levels and time of harvest within the day (Reinink, 1991).

Nitrate contents of organic and conventional vegetables may differ significantly. In Belgium, the mean nitrate contents of organic and conventional products were significantly different, 1703 and $2637 \mathrm{mg} \mathrm{kg}^{-1}$, respectively (Pussemier, Larondelle, Van Peteghem, \& Huyghebaert, 2006). On the other hand, in a study conducted in Italy, organically grown vegetables contained significantly higher contents of nitrate than did conventionally cultivated products (De Martin \& Restani, 2003).

Regarding the nitrite contents, four samples (two turnip sprouts "Grelos" and two Portuguese cabbages) presented nitrite levels $>20 \mathrm{mg} \mathrm{kg}^{-1}$ (Table 1). These values are higher than those that are usually reported in fresh vegetable samples. It is commonly assumed that the nitrite levels in fresh leafy vegetables are usually less than $2 \mathrm{mg} \mathrm{kg}^{-1}$ (Santamaria, 2006). In this study, nitrite levels were lower than $5 \mathrm{mg} \mathrm{kg}^{-1}$ in $70 \%$ of the analysed samples and lower than $20 \mathrm{mg} \mathrm{kg}^{-1}$ in $90 \%$ of the total.

It has been shown that nitrite concentrations in fresh, uninjured, well-stored vegetables are extremely low, possibly because the nitrite reductase activity rate is in equilibrium with one of the nitrate reductase enzymes under proper storage conditions (Chung, Chou, \& Hwang, 2004). Nitrite concentrations may increase dramatically via microbiological reduction of nitrate in vegetables while the nitrate content decreases during storage at ambient temperature. Under refrigerated storage, however, nitrite accumulation tends to be inhibited but may take place (Chung et al., 2004; Prasad \& Chetty, 2008). Under frozen storage, nitrite accumulation is inhibited. Therefore, a poor storage could probably

Table 2

Nitrate and nitrite mean contents $\left(\mathrm{mg} \mathrm{kg}^{-1}\right)$ for the different vegetable samples.

\begin{tabular}{|c|c|c|c|c|c|c|c|c|c|}
\hline \multirow[t]{2}{*}{$\begin{array}{l}\text { Vegetable } \\
\text { (common name and specie) }\end{array}$} & \multirow[b]{2}{*}{$n$} & \multicolumn{4}{|c|}{$\begin{array}{l}\text { Nitrate } \\
\left(\mathrm{mg} \mathrm{kg}^{-1}\right)\end{array}$} & \multicolumn{4}{|c|}{$\begin{array}{l}\text { Nitrite } \\
\left(\mathrm{mg} \mathrm{kg}^{-1}\right)\end{array}$} \\
\hline & & Min & Max & Mean & SD & Min & Max & Mean & $\mathrm{SD}$ \\
\hline $\begin{array}{l}\text { Portuguese cabbage } \\
\quad \text { Brassica oleracea var. costata }\end{array}$ & 9 & 41 & 939 & 547 & 323 & 0.8 & 30 & 9.6 & 10.6 \\
\hline $\begin{array}{l}\text { Turnip sprouts ("grelos") } \\
\text { Brassica rapa var. rapa }\end{array}$ & 7 & 54 & 1447 & 489 & 471 & 1.1 & 57 & 14.8 & 23.5 \\
\hline $\begin{array}{l}\text { Kale ("Couve galega") } \\
\quad \text { Brassica oleracea var. acephala }\end{array}$ & 7 & 41 & 1319 & 472 & 464 & 1.2 & 4.4 & 2.8 & 1.2 \\
\hline $\begin{array}{l}\text { Parsley } \\
\quad \text { Petroselinum crispum }\end{array}$ & 5 & 9 & 2440 & 891 & 970 & 1.3 & 13.4 & 6.2 & 5.6 \\
\hline $\begin{array}{l}\text { Spinach } \\
\quad \text { Spinacea oleracea }\end{array}$ & 2 & 797 & 1427 & 1112 & & 5.2 & 13.8 & 9.5 & \\
\hline $\begin{array}{l}\text { Turnip (root) } \\
\text { Brassica rapa var. rapa }\end{array}$ & 2 & 234 & 654 & 444 & & 1.1 & 1.4 & 1.3 & \\
\hline $\begin{array}{l}\text { Letuce } \\
\qquad \text { Lactuca sativa }\end{array}$ & 1 & & & 1156 & & & & 2.6 & \\
\hline $\begin{array}{c}\text { Colza ("Couve-nabiça) } \\
\text { Brassica napus }\end{array}$ & 1 & & & 73 & & & & 2.2 & \\
\hline
\end{tabular}

$\mathrm{n}$ : number of samples; SD: Standard deviation. 
Table 3

Nitrate contents $\left(\mathrm{mg} \mathrm{kg}^{-1}\right)$ in fresh vegetables (cabbage, lettuce, parsley, spinach and turnip) described in some recent studies.

\begin{tabular}{|c|c|c|c|c|c|c|c|c|}
\hline \multirow[t]{2}{*}{ Vegetable } & \multirow{2}{*}{$\begin{array}{l}\text { Year } \\
\text { reported }\end{array}$} & \multirow[t]{2}{*}{ Author } & \multirow[t]{2}{*}{ Country } & \multicolumn{3}{|c|}{ Nitrate $\left(\mathrm{mg} \mathrm{kg}^{-1}\right)$} & \multirow{2}{*}{$\begin{array}{l}\text { Number of } \\
\text { samples }\end{array}$} & \multirow[t]{2}{*}{ Notes } \\
\hline & & & & Mean & Minimum & Maximum & & \\
\hline \multirow[t]{10}{*}{ Cabbage } & 1999 & Fytianos and Zarogiannis (1999) & Greece & 209 & 19.6 & 414 & 10 & \\
\hline & 2002 & Zhong et al. (2002) & China & 1530 & 26 & 2670 & & North China (1998-1999) \\
\hline & 2003 & Chung et al. (2003) & Korea & 730 & 29 & 1498 & 15 & Winter (November-March), 1998 \\
\hline & & & & 722 & 1 & 1788 & 25 & Summer (April-October), 1998 \\
\hline & 2006 & Tamme et al. (2006) & Estonia & 437 & 74 & 1138 & 168 & $(2003-2004)^{\mathrm{a}}$ \\
\hline & 2006 & Sušin, Kmecl, and Gregorc ic (2006) & Slovenia & 881 & 112 & 1864 & 52 & $(1996-2002)^{\mathrm{a}}$ \\
\hline & 2007 & Thomson et al. (2007) & New Zealand & 241 & 88 & 503 & 8 & November-December, 2003; 2 urban regions \\
\hline & 2008 & Menard et al. (2008) & France & 498 & - & 1855 & 16 & Green cabbage $(2000-2006)^{\mathrm{a}}$ \\
\hline & & & & & & & & $6.3 \%$ of the samples $<$ LOD \\
\hline & 2008 & Prasad and Chetty (2008) & Fiji & 1425 & & & 6 & "English cabbage", $\mathrm{SD}=732 \mathrm{mg} \mathrm{kg}^{-1}(2006)$ \\
\hline \multirow[t]{16}{*}{ Lettuce } & 1999 & Fytianos and Zarogiannis (1999) & Greece & 282 & 8 & 808 & 12 & \\
\hline & 2000 & Ximenes et al. (2000) & Brazil & 1420 & - & - & 1 & \\
\hline & 2000 & Zhou et al. (2000) & China & 896 & 580 & 1454 & 6 & Beijing City $(1979-1981)$ \\
\hline & 2003 & Chung et al. (2003) & Korea & 1933 & 247 & 3283 & 15 & Winter (November-March), 1998 \\
\hline & & & & 2728 & 884 & 4488 & 25 & Summer (April-October), 1998 \\
\hline & 2003 & De Martin and Restani (2003) & Italy & 1473 & $<$ LOD & 3270 & 177 & $(1996-2002)$ \\
\hline & 2006 & Tamme et al. (2006) & Estonia & 2167 & 397 & 3230 & 14 & $(2003-2004)^{\mathrm{a}}$ \\
\hline & 2006 & Sušin et al. (2006) & Slovenia & 1074 & 21 & 3986 & 151 & $(1996-2002)^{\mathrm{a}}$ \\
\hline & 2006 & Weightman et al. (2006) & UK & 838 & - & - & 60 & Goodison var., open field, September 2003 \\
\hline & & & & 1352 & - & - & 60 & Iceberg var., open field, September 2003 \\
\hline & 2006 & $\begin{array}{l}\text { Merino, Darnerud, Edberg, Åman, and Castillo } \\
\text { (2006) }\end{array}$ & Sweden & $2684^{\mathrm{b}}$ & 58 & 5406 & 159 & $\begin{array}{l}\text { Fresh lettuce, under covered fields (1996- } \\
2005)^{\mathrm{a}}\end{array}$ \\
\hline & & & & $826^{\mathrm{b}}$ & 442 & 2038 & 14 & Fresh lettuce, organic farming $(1996-2005)^{\mathrm{a}}$ \\
\hline & & & & $931^{\mathrm{b}}$ & 94 & 2298 & 71 & Iceberg lettuce $(1996-2005)^{\mathrm{a}}$ \\
\hline & 2007 & Thomson et al. (2007) & New Zealand & 1160 & 61 & 2495 & 18 & November-December, 2003; 2 urban regions \\
\hline & 2008 & Menard et al. (2008) & France & 1974 & - & 5600 & 579 & $(2000-2006)^{\mathrm{a}}$ \\
\hline & 2008 & Prasad and Chetty (2008) & Fiii & 1297 & & & 6 & $\begin{array}{l}1.9 \% \text { of the samples }<\text { LOD } \\
\text { SD }=348 \mathrm{~m} \mathrm{ko}^{-1}(2006)\end{array}$ \\
\hline \multirow{3}{*}{ Parsley } & (2009 & Öztekin Nutku and Frim (อمอ९) & Turkev & 1204 & 1204 & & 1 & \\
\hline & $\begin{array}{l}2002 \\
2006\end{array}$ & Oztekm, Nutku, and Erim (2002) & Estonia & $\begin{array}{r}1204 \\
966\end{array}$ & $\begin{array}{r}1204 \\
674\end{array}$ & 1204 & 1 & $\left(2003-20044^{\mathrm{a}}\right.$ \\
\hline & 2008 & Menard et al. (2008) & France & 1980 & - & 4300 & 16 & $(2000-2006)^{\mathrm{a}} ; 6.3 \%$ of the samples <LOD \\
\hline \multirow[t]{12}{*}{ Spinach } & 1999 & Fytianos and Zarogiannis (1999) & Greece & 1250 & 545 & 3760 & 10 & \\
\hline & 2000 & Ximenes et al. (2000) & Brazil & 528 & - & - & 1 & \\
\hline & 2000 & Zhou et al. (2000) & China & 2358 & 239 & 3872 & 35 & Beijing City (1979-1981) \\
\hline & 2002 & Öztekin et al. (2002) & Turkey & 2820 & 2820 & 2820 & 1 & \\
\hline & 2003 & Chung et al. (2003) & Korea & 3334 & 427 & 7439 & 15 & Winter (November-March), 1998 \\
\hline & & & & 4814 & 195 & 7793 & 25 & Summer (April-October), 1998 \\
\hline & 2003 & De Martin and Restani (2003) & Italy & 1757 & $<\mathrm{LOD}$ & 3720 & 23 & $(1996-2002)$ \\
\hline & 2005 & Jaworska (2005a) & Poland & 900 & & & & $\mathrm{SD}=264 \mathrm{mg} \mathrm{kg}^{-1} ;$ New Zealand spinach \\
\hline & 2006 & Tamme et al. (2006) & Estonia & 2508 & 2508 & 2508 & 1 & $(2003-2004)^{\mathrm{a}}$ \\
\hline & 2006 & Merino et al. (2006) & Sweden & $1747^{\mathrm{b}}$ & 47 & 5975 & 63 & Fresh spinach $(1996-2005)^{\mathrm{a}}$ \\
\hline & 2007 & Thomson et al. (2007) & New Zealand & 722 & 73 & 1138 & 8 & November-December, 2003; 2 urban regions \\
\hline & 2008 & Menard et al. (2008) & France & 1682 & - & 8700 & 266 & $(2000-2006)^{\mathrm{a}} ; 3.4 \%$ of the samples $<\mathrm{LOD}$ \\
\hline \multirow[t]{4}{*}{ Turnip } & 2000 & Ximenes et al. (2000) & Brazil & 2098 & - & - & 1 & \\
\hline & 2000 & Zhou et al. (2000) & China & 2127 & & & 1 & Beijing City (1979-1981) \\
\hline & 2006 & Tamme et al. (2006) & Estonia & 307 & 64 & 1062 & 58 & $(2003-2004)^{\mathrm{a}}$ \\
\hline & 2008 & Menard et al. (2008) & France & 657 & - & 2128 & 42 & $(2000-2006)^{\mathrm{a}}$ \\
\hline
\end{tabular}

SD: standard deviation; var.: variety.

${ }^{b}$ Value refers to median. 
result in bacterial growth which can contribute to the increasing accumulation of high nitrite levels (Chung et al., 2004).

In some studies, the contribution of nitrite is disregarded, considering its low level when compared to nitrate. Therefore the results reported for nitrate in those particular studies are in fact the sum of nitrite and nitrate levels (Prasad \& Chetty, 2008; Ximenes et al., 2000).

As regards nitrite levels described in some different studies (Table 4), values $<4.77 \mathrm{mg} \mathrm{kg}^{-1}$ were shown for cabbage. For lettuce, a maximum value of $25 \mathrm{mg} \mathrm{kg}^{-1}$ was presented by Menard et al. (2008) and for spinach a maximum of $220 \mathrm{mg} \mathrm{kg}^{-1}$ was reported. For spinach, although $92 \%$ of the 112 samples showed nitrite levels <LOD, the estimate of the average nitrite concentration reported is $10.2-18.9 \mathrm{mg} \mathrm{kg}^{-1}$. Fytianos and Zarogiannis (1999) reported nitrite values in the range $0.8-8.5 \mathrm{mg} \mathrm{kg}^{-1}$ in spinach, with a mean value of $4.0 \mathrm{mg} \mathrm{kg}^{-1}$. Although these results are not discussed by the authors, such high levels may be due to the microbial reduction of nitrates to nitrites at room temperature or even under refrigeration. In Portugal, in many supermarkets, during daytime, fresh vegetables, such as spinaches, are normally displayed at room temperature. Therefore nitrate conversion to nitrite may occur and nitrite levels higher than those usually reported in the literature may be observed, especially for those species with naturally high nitrate levels. Considering this possibility, the techniques used in nitrate assessment in commercial vegetable samples should account for the different contributions of both nitrate and nitrite.

According to Chung et al. (2003), there was no significant difference in nitrite levels of vegetables harvested between the summer and the winter. During the storage period, the content of nitrites in frozen spinach products, previously cooked in boiling water for $4 \mathrm{~min}$, increased by $27-42 \%$ but did not exceed $1 \mathrm{mg} \mathrm{NO}-\mathrm{kg}^{-1}$ (Jaworska, 2005b).

The nitrate and nitrite contents of the vegetables contribute to the dietary exposure to nitrate and nitrite. This exposure has been assessed in some recent studies and the results are occasionally compared to the acceptable daily intake (ADI) values. An ADI for nitrate of $0-3.7 \mathrm{mg} \mathrm{NO}_{3}^{-} \mathrm{kg}^{-1}$ body weight (bw) has been set by the Joint Expert Committee of the Food and Agriculture (JEFCA) of the United Nations/World Health Organization (WHO) and the European Commission's Scientific Committee on Food (SCF). For nitrite, the JEFCA and the SCF have proposed an ADI of 0-0.07 and 0$0.06 \mathrm{mg} \mathrm{NO}_{2}^{-} \mathrm{kg}^{-1} \mathrm{bw}$, respectively (Santamaria, 2006).

Pennington (1998) discussed several approaches for estimating dietary exposure to nitrate and nitrite and reported some estimates of nitrate and/or nitrite in daily diets from 1973 to 1997 . Intake values can differ to a large extent, depending on the method used for the estimation of additive and contaminant intakes from food (Pennington, 1998; Tamme et al., 2006).

Regarding nitrate, the mean total daily intake per person in Europe ranges between 50 and $140 \mathrm{mg}$ and in the USA about 40$100 \mathrm{mg}$ (Tamme et al., 2006). A comparison of the intake of nitrate and nitrite from vegetables in different countries, with a special focus on recent reports, is shown in Table 5 .

The total intake calculated from nine vegetables that account for $80 \%$ of the total consumption in the north Chinese diet was $423 \mathrm{mg} \mathrm{day}{ }^{-1}$ for nitrate and $0.68 \mathrm{mg} \mathrm{day}^{-1}$ for nitrite (Zhong et al., 2002). In New Zealand, the mean dietary exposure to nitrate

Table 4

Nitrite contents $\left(\mathrm{mg} \mathrm{kg}^{-1}\right)$ in fresh vegetables (cabbage, lettuce, parsley, spinach and turnip) described in some recent studies.

\begin{tabular}{|c|c|c|c|c|c|c|c|c|}
\hline \multirow[t]{2}{*}{ Vegetable } & \multirow{2}{*}{$\begin{array}{l}\text { Year } \\
\text { reported }\end{array}$} & \multirow[t]{2}{*}{ Author } & \multirow[t]{2}{*}{ Country } & \multicolumn{3}{|c|}{ Nitrite $\left(\mathrm{mg} \mathrm{kg}^{-1}\right)$} & \multirow{2}{*}{$\begin{array}{l}\text { Number of } \\
\text { samples }\end{array}$} & \multirow[t]{2}{*}{ Notes } \\
\hline & & & & Mean & Minimum & Maximum & & \\
\hline \multirow[t]{6}{*}{ Cabbage } & 2002 & Zhong et al. (2002) & China & 0.472 & $<\mathrm{LOD}$ & 4.77 & 23 & North China (1998-1999) \\
\hline & 2003 & Chung et al. (2003) & Korea & 0.4 & $<\mathrm{LOD}$ & 3.6 & 15 & Winter (November-March), 1998 \\
\hline & & & & 0.3 & $<\mathrm{LOD}$ & 2.2 & 25 & Summer (April-October), 1998 \\
\hline & 2006 & Sušin et al. (2006) & Slovenia & 0.2 & LOQ & 0.4 & 52 & $\begin{array}{l}(1996-2002)^{\mathrm{a}} ; \mathrm{LOQ}=0.16 \mathrm{mg} \mathrm{kg}^{-1} ; 79 / \\
151<\mathrm{LOQ}\end{array}$ \\
\hline & 2007 & Thomson et al. (2007) & $\begin{array}{l}\text { New } \\
\text { Zealand }\end{array}$ & $<\mathrm{LOD}$ & & & 8 & $\begin{array}{l}\text { November-December, 2003; } 2 \text { urban regions } \\
\text { LOD }=3.33 \mathrm{mg} \mathrm{kg}^{-1}\end{array}$ \\
\hline & 2008 & Menard et al. (2008) & France & $<\mathrm{LOD}$ & & & 7 & Green cabbage $(2000-2006)^{\mathrm{a}}$ \\
\hline \multirow[t]{6}{*}{ Lettuce } & 2000 & Zhou et al. (2000) & China & 0.21 & 0.01 & 0.45 & 6 & Beijing City (1979-1981) \\
\hline & 2003 & Chung et al. (2003) & Korea & 0.6 & $<\mathrm{LOD}$ & 2.9 & 15 & Winter (November-March), 1998 \\
\hline & & & & 0.7 & $<\mathrm{LOD}$ & 4.6 & 25 & Summer (April-October), 1998 \\
\hline & 2006 & Sušin et al. (2006) & Slovenia & 0.3 & LOQ & 1.4 & 151 & $\begin{array}{l}(1996-2002)^{\mathrm{a}} ; \mathrm{LOQ}=0.16 \mathrm{mg} \mathrm{kg}^{-1} ; 47 / 52 \\
\text { samples }<\mathrm{LOQ}\end{array}$ \\
\hline & 2007 & Thomson et al. (2007) & $\begin{array}{l}\text { New } \\
\text { Zealand }\end{array}$ & $<\mathrm{LOD}$ & & & 18 & $\begin{array}{l}\text { November-December, 2003; } 2 \text { urban regions } \\
\text { LOD }=3.33 \mathrm{mg} \mathrm{kg}^{-1}\end{array}$ \\
\hline & 2008 & Menard et al. (2008) & France & $\begin{array}{l}0.10- \\
6.25^{\mathrm{b}}\end{array}$ & & 25 & 259 & $(2000-2006)^{\mathrm{a}} ; 99.6 \%$ of the samples $<$ LOD \\
\hline Parsley & 2008 & Menard et al. (2008) & France & $<\mathrm{LOD}$ & & & 7 & $(2000-2006)^{a}$ \\
\hline \multirow[t]{7}{*}{ Spinach } & 1999 & $\begin{array}{l}\text { Fytianos and } \\
\text { Zarogiannis (1999) }\end{array}$ & Greece & 4.0 & 0.8 & 8.5 & 12 & \\
\hline & 2000 & Zhou et al. (2000) & China & 0.27 & $<\mathrm{LOD}$ & 0.73 & 6 & Beijing City (1979-1981) \\
\hline & 2003 & Chung et al. (2003) & Korea & 0.5 & $<\mathrm{LOD}$ & 1.8 & 15 & Winter (November-March), 1998 \\
\hline & & & & 1.2 & $<\mathrm{LOD}$ & 5.1 & 25 & Summer (April-October), 1998 \\
\hline & 2005 & Jaworska (2005a) & Poland & 0.34 & & & & $\mathrm{SD}=0.16 ;$ New Zealand spinach \\
\hline & 2007 & Thomson et al. (2007) & $\begin{array}{l}\text { New } \\
\text { Zealand }\end{array}$ & $<\mathrm{LOD}$ & & & 8 & $\begin{array}{l}\text { November-December, 2003; } 2 \text { urban regions } \\
\text { LOD }=3.33 \mathrm{mg} \mathrm{kg}^{-1}\end{array}$ \\
\hline & 2008 & Menard et al. (2008) & France & $\begin{array}{l}10.17- \\
18.88^{\mathrm{b}}\end{array}$ & & 220 & 112 & $(2000-2006)^{\mathrm{a}} ; 92 \%$ of the samples $<$ LOD \\
\hline \multirow[t]{2}{*}{ Turnip } & 2000 & Zhou et al. (2000) & China & $<\mathrm{LOD}$ & & & 1 & Beijing City (1979-1981) \\
\hline & 2008 & Menard et al. (2008) & France & $<\mathrm{LOD}$ & & & 13 & $(2000-2006)^{\mathrm{a}}$ \\
\hline
\end{tabular}

LOD: limit of detection; SD: standard deviation; var.: variety.

a National monitoring programme.

b Lower and upper bounds for the estimate of the average concentration. 
Table 5

Comparison of the intakes of nitrate and nitrite from vegetables in different countries $\left(\mathrm{mg} \mathrm{person}^{-1}\right.$ day $\left.^{-1}\right)$ using a basis of $60 \mathrm{~kg}$ body weight.

\begin{tabular}{|c|c|c|c|c|c|c|c|c|}
\hline Country & $\begin{array}{l}\text { Year } \\
\text { report }\end{array}$ & Author & $\begin{array}{l}\text { Vegetable } \\
\text { consumption } \\
\left(\mathrm{g} \mathrm{day}^{-1}\right)\end{array}$ & $\begin{array}{l}\text { Nitrate } \\
\text { intake } \\
\left(\mathrm{mg} \mathrm{day}^{-1}\right)\end{array}$ & $\begin{array}{l}\text { Nitrite } \\
\text { intake } \\
\left(\mathrm{mg} \mathrm{day}^{-1}\right)\end{array}$ & $\begin{array}{l}\% \mathrm{ADI} \\
\text { nitrate }\end{array}$ & $\begin{array}{l}\% \mathrm{ADI} \\
\text { nitrite }\end{array}$ & Notes \\
\hline China & 2002 & Zhong et al. (2002) & 444 & 422.8 & 0.68 & 219 & & $\begin{array}{l}\text { North China; nine vegetables that } \\
\text { account for } 80 \% \text { of the total } \\
\text { consumption in the north Chinese diet }\end{array}$ \\
\hline Denmark & 1999 & $\begin{array}{l}\text { Petersen and Stoltze } \\
\text { (1999) }\end{array}$ & 142 & 38.9 & 0.091 & & & \\
\hline England & 1999 & Ysart et al. (1999) & 322 & 109 & 2.2 & & & \\
\hline Egypt & 1998 & $\begin{array}{l}\text { Saleh, Brunn, Paetzold, } \\
\text { and Hussein (1998) }\end{array}$ & 159 & 296 & - & $\begin{array}{l}116(\mathrm{~F}) \\
140(\mathrm{M})\end{array}$ & & $\left(\mathrm{NO}_{2}^{-}+\mathrm{NO}_{3}^{-}\right) ;$total diet study \\
\hline \multirow[t]{2}{*}{ France } & 2008 & Menard et al. (2008) & 67.1 & & & 27 & $<0.05-33.3$ & $\begin{array}{l}\text { Adults ( }>15 \text { year-old), } n=1474 \\
\text { excluding potatoes }\end{array}$ \\
\hline & & & 111 & 90 & $1.2-2.4$ & 24.3 & $<0.05-16.7$ & $\begin{array}{l}\text { Adults ( }>15 \text { year-old), } n=1474 \\
\text { excluding potatoes }\end{array}$ \\
\hline Korea & 2003 & Chung et al. (2003) & 104 & 182 & 0.12 & & & Chinese cabbages only \\
\hline \multirow[t]{2}{*}{ Italy } & 2003 & $\begin{array}{l}\text { De Martin and Restani } \\
\text { (2003) }\end{array}$ & 34.1 & 65.8 & - & 29.8 & & $\begin{array}{l}\text { Adults; includes the five most } \\
\text { consumed vegetables, supposed to } \\
\text { provide most of the nitrate intake in } \\
\text { the typical Italian diet }\end{array}$ \\
\hline & & & 8.5 & 14.5 & & 19.6 & & $\begin{array}{l}\text { Children ( } 4-6 \text { years, bw }=20 \mathrm{~kg}) \text {; } \\
\text { includes the } 5 \text { most consumed } \\
\text { vegetables, supposed to provide most } \\
\text { of the nitrate intake in the typical adult } \\
\text { Italian diet }\end{array}$ \\
\hline \multirow[t]{3}{*}{ Estonia } & 2006 & Tamme et al. (2006) & 376 & 58 & & 26 & & $\begin{array}{l}\text { Adults, Consumption Survey National } \\
\text { Board of Statistics }\end{array}$ \\
\hline & & & 226 & 30 & & 40 & & $\begin{array}{l}\text { Children ( } 4-6 \text { year-old), two } \\
\text { kindergarten menu consumption } \\
\text { survey }\end{array}$ \\
\hline & & & 198 & 26 & & 52 & & $\begin{array}{l}\text { Children ( } 1-3 \text { year-old), recommended } \\
\text { infant menu }\end{array}$ \\
\hline New Zealand & 2007 & Thomson et al. (2007) & 231 & 42 & 0.48 & 16 & 13 & Adults; food and water combined. \\
\hline New Zealand & 2004 & & & 31.2 & 0.54 & & & $\begin{array}{l}\text { Total diet, additives plus vegetables, } \\
2004\end{array}$ \\
\hline
\end{tabular}

from food and water combined was estimated to be $16 \%$ of the ADI, with a median exposure level of $9 \%$ of the ADI. Approximately $1 \%$ of exposure scenarios resulted in daily dietary exposures above the ADI for nitrate (Thomson et al., 2007). The most significant contributors were potatoes $(32 \%)$ and lettuce $(29 \%)$. The mean dietary exposure to exogenous nitrite was about $13 \%$ of the ADI, excluding endogenous conversion of nitrate. If a contribution from the conversion of dietary nitrate to nitrite was considered, the ADI was exceeded $10 \%$ of the time for an average conversion rate $(5 \%)$ and $50 \%$ of the time for individuals with high conversion rate $(20 \%)$ (Thomson et al., 2007).

Nitrate dietary exposure in France averaged $40 \%$ of the ADI for adults and 51-54\% for children (Menard et al., 2008). The major contributors were, for adults and children, respectively, vegetables ( $24 \%$ and $27 \%$ of ADI), potatoes ( $5 \%$ and $11 \%$ of ADI) and water $(5 \%$ and $5 \%$ of the ADI). Nitrite dietary exposure averaged $33-67 \%$ of the ADI for adults and $67-133 \%$ for children. This was the first French estimate of the dietary exposure to nitrate and nitrite based on concentrations analysed in foods (13,657 analyses in foods and 6870 analyses in water) (Menard et al., 2008).

The knowledge of the nitrate and nitrite metabolisms in $\mathrm{hu}^{-}$ mans and their toxicological effects must be improved to better characterise the risk of dietary exposure to nitrate and nitrite present in food (Menard et al., 2008). Case-control studies examining dietary intake of nitrate and the risk of gastric cancer have consistently found a negative association (Kelley \& Duggan, 2003). In such studies, vegetable intake has been consistently related to a decreased risk of gastric cancer. Nitrate intake was probably an index of vegetable intake, which can explain the negative association. Recent case-control studies have all reported a weak, statistically non-significant increased risk of gastric cancer for high vs. low nitrite intake. Nitrite intake may be related to the con- sumption of preserved meat, typically high-salt foods, which can also contribute to an increased risk of gastric cancer. It is interesting to note that a diet high in nitrite does not appear to confer an increased risk if that diet is also high in antioxidants from fruits and vegetables (Kelley \& Duggan, 2003).

\section{Conclusions}

Growing concern over nitrate toxicity has produced a number of studies on nitrate and nitrite contents of fresh vegetable samples. Nitrite and nitrate levels of 34 vegetable samples, from an intensive horticultural area in north Portugal, were determined and their levels compared to those reported in recent literature. No maximum limits established for nitrate were exceeded and the results are in the range of others reported in different countries. According to actual knowledge, the ingestion of these vegetables is supposed to be beneficial for the population despite their nitrate and nitrite contents.

\section{References}

Choi, S. Y., Chung, M. J., Lee, S.-J., Shin, J. H., \& Sung, N. J. (2007). N-nitrosamine inhibition by strawberry, garlic, kale, and the effects of nitrite-scavenging and $\mathrm{N}^{-}$ nitrosamine formation by functional compounds in strawberry and garlic. Food Control, 18, 485-491.

Chung, J.-C., Chou, S.-S., \& Hwang, D.-F. (2004). Changes in nitrate and nitrite content of four vegetables during storage at refrigerated and ambient temperatures. Food Additives and Contaminants, 21(4), 317-322.

Chung, S. Y., Kim, J. S., Kim, M., Hong, M. K., Lee, J. O., Kim, C. M., et al. (2003). Survey of nitrate and nitrite contents of vegetables grown in Korea. Food Additives and Contaminants, 20(7), 621-628.

De Martin, S., \& Restani, P. (2003). Determination of nitrates by a novel ion chromatographic method: Occurrence in leafy vegetables (organic and conventional) and exposure assessment for Italian consumers. Food Additives and Contaminants, 20(9), 787-792. 
European Commission (2006). Commission regulation (EC) No. 1881/2006 of 19 December 2006 setting maximum levels for certain contaminants in foodstuffs.

Fytianos, K., \& Zarogiannis, P. (1999). Nitrate and nitrite accumulation in fresh vegetables from Greece. Bulletin of Environmental Contamination and Toxicology, $62,187-192$.

Gonçalves, C., Esteves da Silva, J. C. G., \& Alpendurada, M. F. (2006). Chemometric interpretation of pesticide occurrence in soil samples from an intensive horticulture area in north Portugal. Analytica Chimica Acta, 560, 164171.

Gruda, N. (2005). Impact of environmental factors on product quality of greenhouse vegetables for fresh consumption. Critical Reviews in Plant Sciences, 24, 227247.

ISO 6635:1984 (E). Fruits, vegetables and derived products - Determination of nitrite and nitrate content - Molecular absorption spectrometric method. International Organization for Standardization, Geneve, Switzerland.

Jaworska, G. (2005a). Content of nitrates, nitrites and oxalates in New Zealand spinach. Food Chemistry, 89, 235-242.

Jaworska, G. (2005b). Nitrates, nitrites, and oxalates in products of spinach and New Zealand spinach. Effect of technological measures and storage time on the level of nitrates, nitrites, and oxalates in frozen and canned products of spinach and New Zealand spinach. Food Chemistry, 93, 395-401.

Kelley, J. R., \& Duggan, J. M. (2003). Gastric cancer epidemiology and risk factors. Journal of Clinical Epidemiology, 56, 1-9.

Menard, C., Heraud, F., Volatier, J.-L., \& Leblanc, J.-C. (2008). Assessment of dietary exposure of nitrate and nitrite in France. Food Additives and Contaminants, 25(8), 971-988.

Merino, L., Darnerud, P. O., Edberg, U., Åman, P., \& Castillo, M. D. P. (2006). Levels of nitrate in Swedish lettuce and spinach over the past 10 years. Food Additives and Contaminants, 23(12), 1283-1289.

Öztekin, N., Nutku, M. S., \& Erim, F. B. (2002). Simultaneous determination of nitrite and nitrate in meat products and vegetables by capillary electrophoresis. Food Chemistry, 76, 103-106.

Pennington, J. A. T. (1998). Dietary exposure models for nitrates and nitrites. Food Control, 9(6), 385-395.

Petersen, A., \& Stoltze, S. (1999). Nitrate and nitrite in vegetables on the Danish market: Content and intake. Food Additives and Contaminants, 16(7), 291-299

Prasad, S., \& Chetty, A. A. (2008). Nitrate-N determination in leafy vegetables: Study of the effects of cooking and freezing. Food Chemistry, 106, 772-780.
Pussemier, L., Larondelle, Y., Van Peteghem, C., \& Huyghebaert, A. (2006). Chemical safety of conventionally and organically produced foodstuffs: A tentative comparison under Belgian conditions. Food Control, 17, 14-21.

Reinink, K. (1991). Genotype $\mathrm{x}$ environment interaction for nitrate concentration in lettuce. Plant Breeding, 107, 39-49.

Saleh, Z. A., Brunn, H., Paetzold, R., \& Hussein, L. (1998). Nutrients and chemical residues in an Egyptian total mixed diet. Food Chemistry, 63(4), 535-541.

Santamaria, P. (2006). Nitrate in vegetables: Toxicity, content, intake and EC regulation (review). Journal of the Science of Food and Agriculture, 86, 10-17.

Silva, S., Sousa, J., Ramalhosa, M. J., Barroso, M. F., Antão, M. C., Pina, M. F., DelerueMatos, C. (2006). Incidence of nitrate, nitrite, chloride and phosphate in groundwater in Modivas, Portugal. In Proceedings of international water conference, Porto, Portugal, 12-14 June.

Sušin, J., Kmecl, V., \& Gregorc`ic, A. (2006). A survey of nitrate and nitrite content of fruit and vegetables grown in Slovenia during 1996-2002. Food Additives and Contaminants, 23(4), 385-390.

Tamme, T., Reinik, M., Roasto, M., Juhkam, K., Tenno, T., \& Kiis, A. (2006). Nitrates and nitrites in vegetables and vegetable-based products and their intakes by the Estonian population. Food Additives and Contaminants, 23(4), 355-361.

Thomson, B. M., Nokes, C. J., \& Cressey, P. J. (2007). Intake and risk assessment of nitrate and nitrite from New Zealand foods and drinking water. Food Additives and Contaminants, 24(2), 113-121.

Weightman, R. M., Dyer, C., Buxton, J., \& Farrington, D. S. (2006). Effects of light level, time of harvest and position within field on the variability of tissue nitrate concentration in commercial crops of lettuce (Lactuca sativa) and endive (Cichorium endiva). Food Additives and Contaminants, 23(5), 462-469.

Ximenes, M. I. N., Rath, S., \& Reyes, F. G. R. (2000). Polarographic determination of nitrate in vegetables. Talanta, 51, 49-56.

Yordanov, N. D., Novakova, E., \& Lubenova, S. (2001). Consecutive estimation of nitrate and nitrite ions in vegetables and fruits by electron paramagnetic resonance spectrometry. Analytica Chimica Acta, 437, 131-138.

Ysart, G., Miller, P., Barrett, G., Farrington, D., Lawrance, P., \& Harrison, N. (1999) Dietary exposures to nitrate in the UK. Food Additives and Contaminants, 16(12), 521-532.

Zhong, W., Hu, C., \& Wang, M. (2002). Nitrate and nitrite in vegetables from north China: Content and intake. Food Additives and Contaminants, 19(12), 1125-1129.

Zhou, Z.-Y., Wang, M.-J., \& Wang, J.-S. (2000). Nitrate and nitrite contamination in vegetables in China. Food Reviews International, 16(1), 61-76. 